\title{
Pasture production and botanical composition of high sugar and control ryegrasses with or without endophyte under irrigation in Canterbury
}

\author{
R.H. BRYANT ${ }^{1}$, A.J. PARSONS ${ }^{2}$, S. RASMUSSEN ${ }^{2}$ and G.R. EDWARDS ${ }^{1}$ \\ ${ }^{1}$ Agriculture and Life Sciences Division, PO Box 84, Lincoln University, Canterbury \\ ${ }^{2}$ AgResearch Grasslands Research Centre, PO Box 11008, Palmerston North \\ racheal.bryant@lincoln.ac.nz
}

\begin{abstract}
High sugar grasses and novel endophytes are two new technologies promoted for pastoral farmers. While assessing their value for pastoral farming it is important to consider the interactive effects of these technologies on both pasture production and composition. Pasture production and botanical composition was measured over 2 years for a range of perennial ryegrass cultivars infected with different endophyte strains in grazed small plot trials under irrigation in Canterbury. Cultivar and endophyte strain had little effect on total dry matter production; agronomically the UK-bred high sugar grass performed as well as the New Zealand controls. There was a trend for less white clover with ryegrass cultivars infected with AR1 and AR37 endophyte compared with endophyte-free treatments. Generally, endophyte infection is promoted as being beneficial for ryegrasses. However, under irrigated conditions and low levels of insect pressure, the advantage of endophyte infection was minimal.
\end{abstract}

Keywords: water soluble carbohydrates, Lolium perenne, Trifolium repens, Neotyphodium lolii, dry matter yield

\section{Introduction}

A review of the future of pasture plant breeding by Williams et al. (2007) highlighted how changes in New Zealand's plant breeding has 'stepped-up' the adoption of biotechnologies to improve creation and utilisation of unique plant and endophyte germplasms. For example, the introduction to New Zealand (NZ) of high sugar grasses (HSG) bred and adapted in Europe. These grasses were selected for increased water soluble carbohydrates (WSC) as a means of increasing energy availability, synchronising $\mathrm{N}$ capture in the rumen and increasing microbial protein availability to the animal. Consequently, they are being endorsed as a means of improving animal performance. The success of these new cultivars to improve livestock productivity was reviewed by Edwards et al. (2007a, b). An analysis of global data revealed only small increases in the efficiency of conversion of food protein into milk, and little evidence, to date, of increases in milk yield, that could be attributed to the HSG trait. The review did, however, show proof of concept that HSG diets reduced the proportion of $\mathrm{N}$ eaten that was voided as urine (a potential environmental benefit) but that this depended on sufficient elevation of sugar concentrations, and that this was not consistently evident for pasture systems producing high protein forage, such as in NZ. They also noted that the majority of these evaluations took place in the Northern hemisphere and stressed the need for more field testing in NZ.

To date only three NZ field studies have published results comparing a HSG (cv. 'Aberdart') with either a UK or NZ control. Parsons et al. (2004) compared 'Aberdart' with a UK control in field plots in Palmerston North and saw little difference in WSC between the HSG and the control. This led to a follow-up study in plant growth chambers which showed a strong temperature effect, indicating that the NZ climate may be too warm for full expression of the WSC trait. In Palmerston North, Cosgrove et al. (2007) measured WSC concentration of 'Aberdart' and a NZ control in spring and autumn to examine the effect of HSG on dairy performance. While the HSG contained higher WSC in spring, differences in milk production only occurred in autumn when both cultivars had similar WSC concentration. In a recent Canterbury study, the high sugar trait was expressed in its first year when compared with a NZ control (Bryant et al. 2008b).

What is lacking in these studies, and those conducted overseas, is information on dry matter (DM) yield and botanical composition of mixed-species pastures when cultivars are infected with novel or no endophyte (Nil). The persistence of ryegrass in New Zealand is improved by the presence of endophyte particularly in insect prone and summer dry areas (Hume et al. 2007; Popay et al. 2003). Endophyte infection of perennial ryegrass has also been shown to suppress companion white clover (Sutherland \& Hoglund 1989; Thom et al. 1999), and so reduce the positive contribution of clover to nitrogen budget and nutritive status of mixed-species pasture. The mechanisms of association between host and endophyte are not fully understood but it is agreed that not all hosts will behave in the same manner when infected with similar endophyte strains (Cheplick \& Cho 
2003; Rasmussen et al. 2008). One result of endophyte/ host interaction in HSGs is a reduced endophyte concentration and lower alkaloid production (Bryant et al. 2008b; Rasmussen et al. 2007). Reduced alkaloid concentrations might have long-term implications on pasture persistence in insect prone areas.

A review of perennial ryegrass breeding (Wilkins \& Humphreys 2003) stressed the necessity of combining any improvement in quality traits with plant persistence, tolerance to environmental stress, resistance to pathogen and pests and adequate seed yield. This study reports on yield and botanical composition of mixed-species pastures containing high sugar grasses infected with novel or Nil endophyte grown with irrigation in Canterbury.

\section{Materials and Methods}

The experiment was carried out between December 2006 and April 2009 at Lincoln, Canterbury on a Wakanui silt loam soil $(\mathrm{pH}=5.8$; Olsen $\mathrm{P}=25)$. Treatments consisted of three perennial ryegrass (Lolium perenne) cultivars infected with Neotyphodium lolii endophytes (AR1 or AR37) or Nil. Plots (6 x $4.2 \mathrm{~m})$ were arranged in randomised complete blocks of three. The three cultivars were: a high sugar diploid (cv. 'Aberdart'), a diploid control (cv. 'Grasslands Samson'), and a tetraploid (cv. 'Quartet') which also has high sugar concentration as a result of increased chromosome number. All cultivars were infected with AR1 or Nil while an additional endophyte treatment (AR37) was included in the diploid 'Grasslands Samson'. The AR37 strain was not commercially available in any HSG or tetraploid cultivars at the time of sowing. After cultivation, all plots were drilled on 6 December 2006 with $15 \mathrm{~kg} / \mathrm{ha}$ ryegrass (18 kg/ha 'Quartet') and $3 \mathrm{~kg} /$ ha white clover (Trifolium repens). At sowing plots received one application of urea fertiliser at a rate of $50 \mathrm{~kg} \mathrm{~N} / \mathrm{ha}$. Establishment was assessed 4 weeks after sowing by counting ryegrass plants in two $1 \mathrm{~m}$ drill rows. The experimental area received 2-3 passes of a travelling irrigator between November and April each year at an application rate of $8 \mathrm{~mm} / \mathrm{hr}$.

Dry matter yield was determined pre-and post-grazing from 20 readings/plot of a previously calibrated pasture probe (Mk III C Design Electronics). After grazing, all plots were mown to a uniform height of $6 \mathrm{~cm}$ and residual mass was determined. The plots were grazed

Figure 1 Mean monthly rainfall (black columns), irrigation (stacked columns) and mean monthly air temperature at Lincoln, Canterbury.

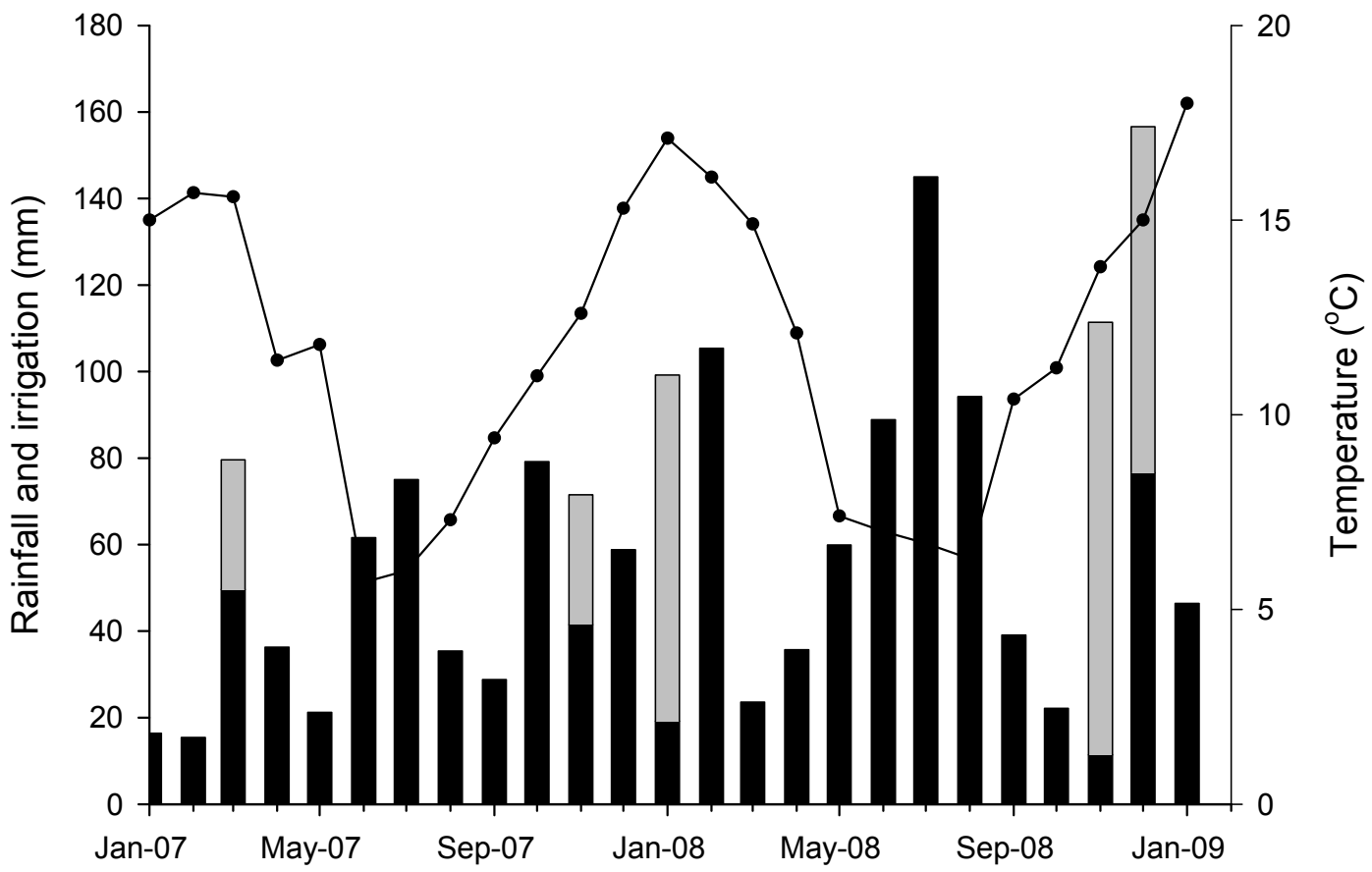


Figure 2 Annual dry matter (DM) yield of three perennial ryegrass cultivars either not infected with endophyte (white), or infected with AR1 (black) or AR37 (grey) endophyte in Year 1 (a) and Year 2 (b).
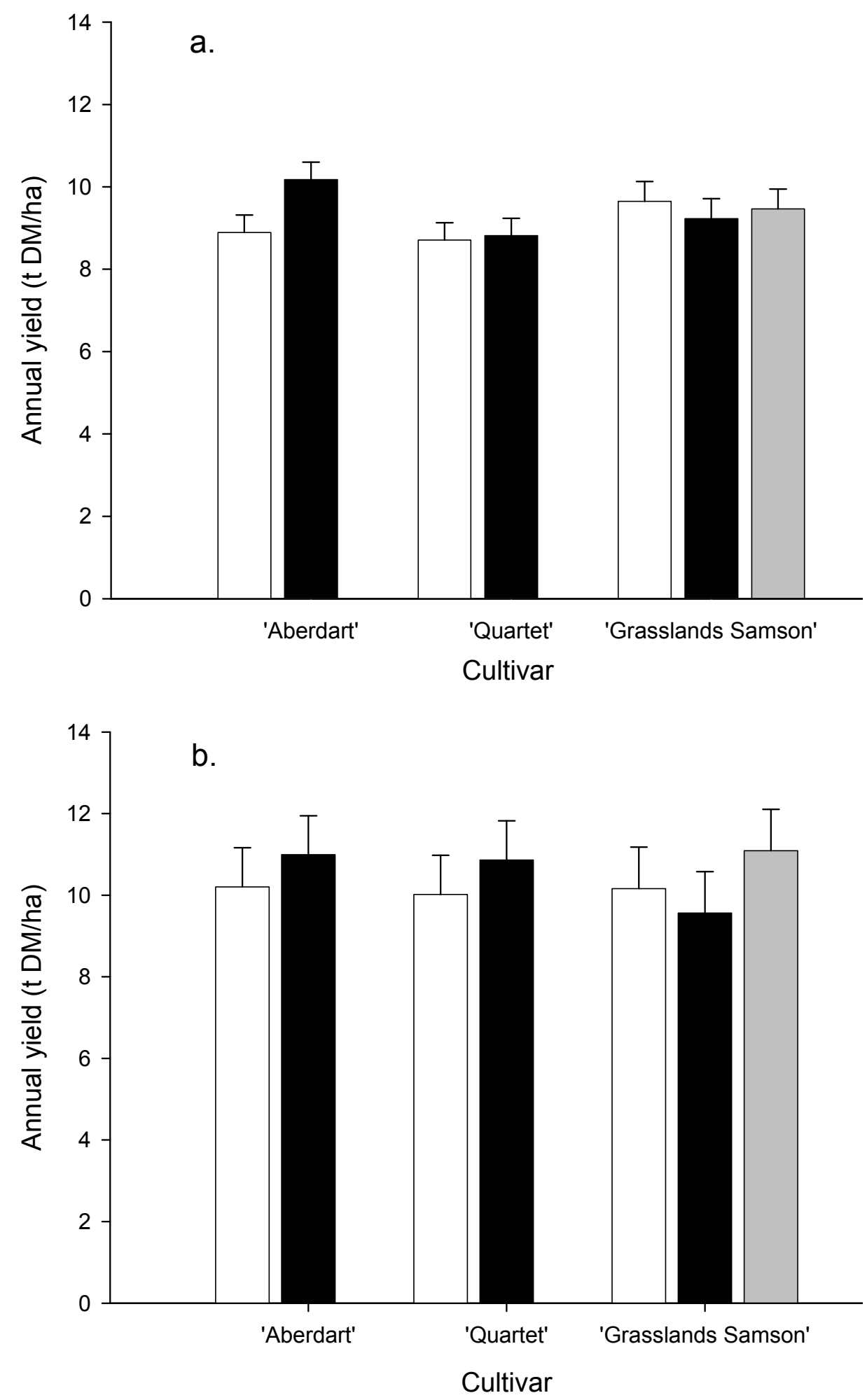
Figure 3 Pasture growth rate of three perennial ryegrass cultivars: 'Grasslands Samson' (triangle), 'Aberdart' (circle) and 'Quartet' (square) infected with AR1 endophyte (closed symbols) or not infected (open symbols). Asterisk indicates significant differences $(P<0.05)$.

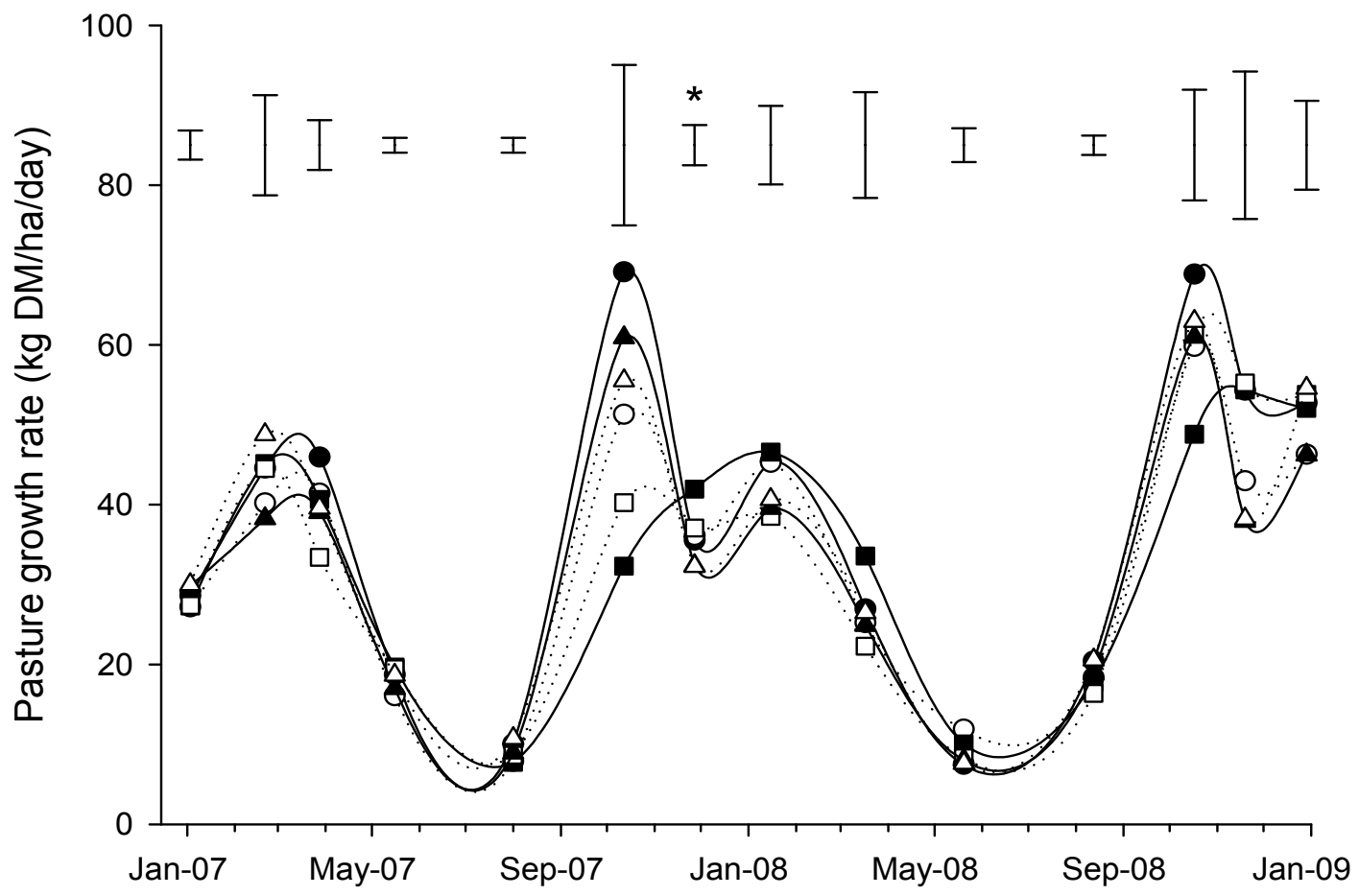

seven times annually with ewe hoggets and annual DM accumulation was determined by $\Sigma$ (current yield - previous mown residual). Mean daily pasture growth rates during each regrowth interval were calculated from $\mathrm{DM}$ accumulation between successive grazings and the length of regrowth interval. Samples of ryegrass leaves were collected between 1300-1400 hr the day before grazing and freeze-dried and ground for near-infrared reflectance spectroscopy (NIRS) determination of WSC concentration. The proportions of ryegrass, clover and weeds were determined each season by calibrated visual observation in Year 1 and from a single $0.2 \mathrm{~m}^{2}$ quadrat cut to $1 \mathrm{~cm}$ in each plot in Year 2. Quadrat cuts were sorted into weeds (broadleaf species and annual grasses), clover and ryegrass, before oven drying for $48 \mathrm{~h}$ at $65^{\circ} \mathrm{C}$ and recording dry weights.

Argentine stem weevil (Listronotus bonariensis) populations were monitored in summer and autumn and tiller death caused by larvae was assessed at peak feeding times in March 2007 and January 2008. Twenty ryegrass tillers from each treatment were cut beneath soil level and and examined for larval feeding on growing points, signifying death of that tiller. Root aphid (Aploneura lentisci) and grass grub (Costelytra zealandica) populations were assessed in April 2008 by digging two turves $(15 \times 15 \times 10 \mathrm{~cm}$ deep) from all 'Grasslands Samson' and 'Aberdart' plots. Turfs were carefully dismantled and grass grubs were removed and counted. Aphid colonies were identified by presence of live aphids surrounded by white wax secretions. To account for differences in colony size and subsequent root feeding, wax secretions greater than $5 \mathrm{~mm}$ in diameter were counted as $2(6-15 \mathrm{~mm})$ or $3(>15 \mathrm{~mm})$ colonies.

All data was analysed for variance in Genstat $v$ 11.1 (VSN International Ltd, 2008) as a $3 \times 2$ factorial design with the factors being cultivar, endophyte and their interaction. The effects of endophyte which would include AR37, were analysed separately using the 'Grasslands Samson' subset with three endophyte levels.

\section{Results}

\section{Dry matter production}

Rainfall in Year 1 was $604 \mathrm{~mm}$ plus three irrigation events totalling $140 \mathrm{~mm}$ between January 2007 and January 2008 (Fig. 1). Higher rainfall $(721 \mathrm{~mm})$ was recorded in Year 2 although nearly half $(330 \mathrm{~mm})$ fell between June and August 2008. Absence of rain in late spring and early summer 2008 prompted an additional $180 \mathrm{~mm}$ of irrigation.

Ryegrass establishment after 4 weeks was similar 
Table 1 Seasonal variation in proportion of clover (\% total DM) for three perennial ryegrass pastures infected with (AR1, AR37) or without (Nil) endophyte.

\begin{tabular}{|c|c|c|c|c|c|c|c|c|c|c|}
\hline & \multirow[b]{2}{*}{ Apr-07 } & \multirow[b]{2}{*}{ Jun-07 } & \multicolumn{5}{|c|}{ Harvest Date } & \multirow[b]{2}{*}{ Dec-08 } & \multirow[b]{2}{*}{ Apr-09 } & \multirow[b]{2}{*}{ Mean } \\
\hline & & & Oct-07 & Dec-07 & Apr-08 & Jun-08 & Sep-08 & & & \\
\hline \multicolumn{11}{|l|}{ Cultivar endophyte } \\
\hline 'Aberdart' Nil & 2.7 & 2.0 & 22.0 & 24.9 & 23.1 & 7.8 & 17.6 & 18.5 & 30.0 & 16.5 \\
\hline ‘G.Samson' Nil & 0.7 & 0.8 & 8.3 & 5.0 & 25.8 & 9.8 & 24.1 & 14.7 & 31.4 & 13.4 \\
\hline 'Quartet' Nil & 3.0 & 1.3 & 10.7 & 13.2 & 22.6 & 2.7 & 25.2 & 13.4 & 19.6 & 12.4 \\
\hline 'Aberdart' AR1 & 1.0 & 0.5 & 4.7 & 18.2 & 20.0 & 11.0 & 18.8 & 8.0 & 25.4 & 12.0 \\
\hline ‘G.Samson' AR1 & 2.0 & 0.5 & 6.0 & 10.5 & 25.6 & 4.6 & 42.8 & 11.8 & 17.6 & 13.5 \\
\hline 'Quartet' AR1 & 1.7 & 1.7 & 14.7 & 49.8 & 21.2 & 6.1 & 11.1 & 5.3 & 13.7 & 13.9 \\
\hline SEM & 0.51 & 0.45 & 5.84 & 10.07 & 6.87 & 2.59 & 8.45 & 3.34 & 5.37 & 2.49 \\
\hline \multicolumn{11}{|l|}{ ‘G.Samson’ } \\
\hline Nil & 0.7 & 0.8 & 8.3 & 5.0 & 25.8 & 9.8 & 24.1 & 14.7 & 31.4 & 13.4 \\
\hline AR1 & 2.0 & 0.5 & 6.0 & 10.5 & 25.6 & 4.6 & 42.8 & 11.8 & 17.6 & 13.5 \\
\hline AR37 & 1.7 & 0.2 & 7.3 & 9.1 & 15.8 & 2.9 & 13.2 & 18.5 & 26.6 & 10.6 \\
\hline SEM & 0.30 & 0.37 & 5.60 & 3.84 & 6.00 & 1.03 & 9.02 & 6.38 & 7.39 & 2.10 \\
\hline
\end{tabular}

Figure 4 Water soluble carbohydrate concentration (WSC, mg/g DM) in leaves of perennial ryegrass cultivars: 'Aberdart' (black columns), 'Quartet' (light grey) and 'Grasslands Samson' (dark grey). Asterisk indicate significant differences $(P<0.05)$.

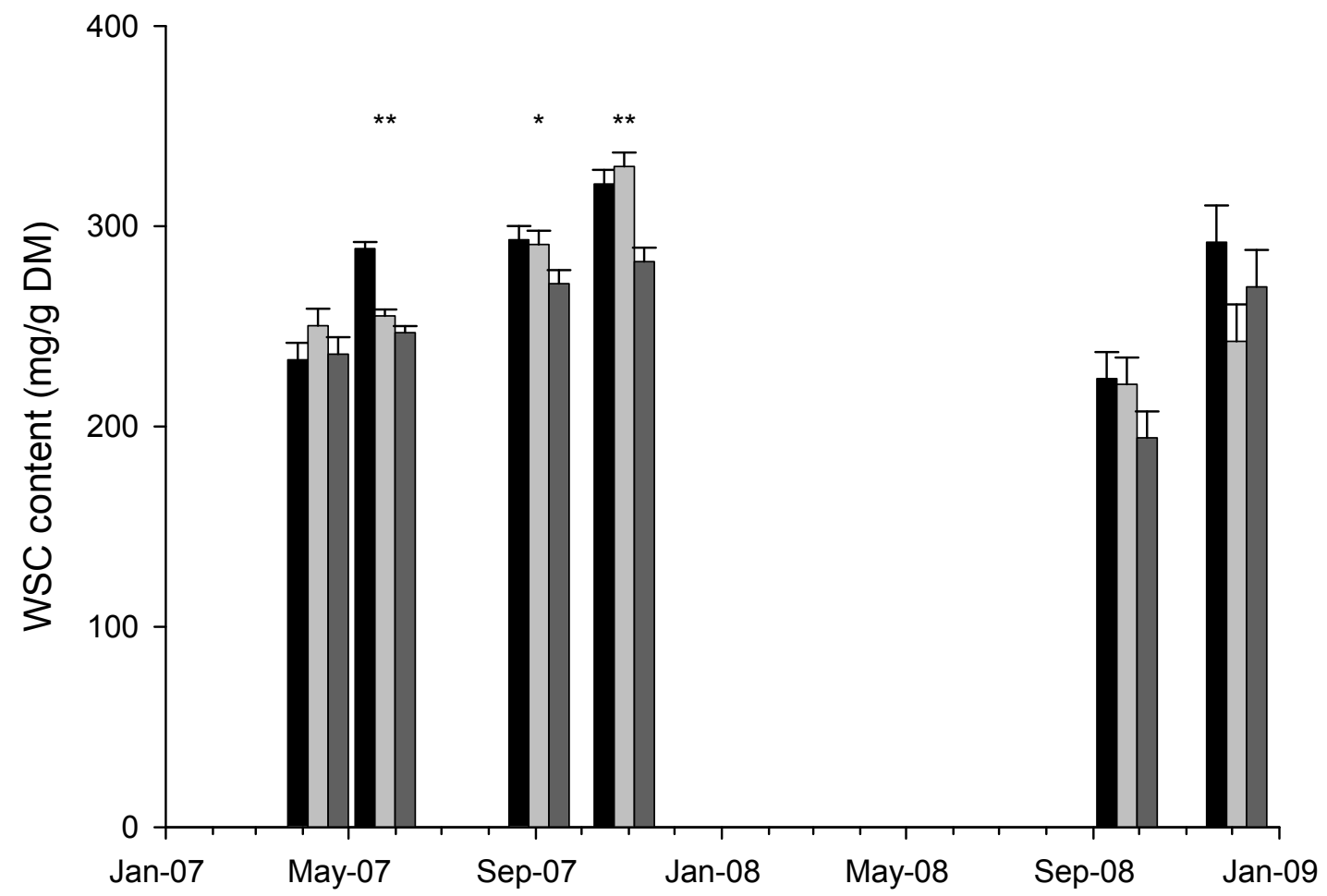


across cultivar and endophyte treatments at 22.8 ( \pm 1.6) plants/m drill row. By the end of Year 1 mean DM yield for all cultivars infected with either AR1 or Nil endophyte was $9.3 \mathrm{t} /$ ha, there was no difference among cultivar or endophyte (Fig. 2). Dry matter production increased in Year $2(10.3 \mathrm{t} \mathrm{DM} / \mathrm{ha}, \mathrm{P}<0.05)$ but again there was no cultivar or endophyte effect. A separate ANOVA of the three endophytes in the 'Grasslands Samson' treatment showed AR1 or AR37 endophyte had no effect on DM yield compared with Nil endophyte pastures.

There was a range in pasture growth rate among treatments (Fig. 3), but because of variability among plots no significant differences were detected. In the first spring, 'Aberdart' and 'Grasslands Samson' had a marginally higher growth rate than the later flowering tetraploid, 'Quartet' $(\mathrm{P}=0.07)$, but by November of the same year the growth rate of 'Quartet' exceeded that of the other cultivars $(\mathrm{P}=0.05)$. There was no evidence that endophyte affected pasture growth rate.

\section{Insect damage}

Tiller death caused by ASW larval feeding was generally low with less than 3\% in January 2008. Pastures were monitored again in November and December 2008, but signs of ASW damage were absent. The highest insect damage occurred at the end of the first summer in March 2007 with death of $9 \%$ of tillers across treatments. During this period there was an endophyte effect $(\mathrm{P}<0.05) ; 15 \%$ of Nil endophyte tillers were killed by larval feeding compared to just $4 \%$ of those infected with AR1. There was no significant preference shown by ASW for high sugar or standard cultivars. The grass grub population in April 2008 was low as only four of the turfs examined possessed grass grub and this was unrelated to either endophyte or cultivar. Root aphids did not show any preference between the two diploids 'Aberdart' and 'Grasslands Samson' (8.8 vs 8.7 aphids, respectively) or Nil or AR1 endophyte (8.3 vs 9.1 aphids, respectively). However, analysis of the 'Grasslands Samson' subset showed a strong aversion to plants infected with AR37 endophyte $(\mathrm{P}<0.05)$. Colony numbers were 8.0, 9.3 and $0.7( \pm 2.04)$ under Nil, AR1 and AR37 endophytes, respectively.

\section{Water soluble carbohydrates}

Water soluble carbohydrate concentration was generally high with values ranging from 194 to $330 \mathrm{mg} / \mathrm{g}$ DM (Fig. 4). 'Aberdart' had significantly higher WSC than did the standard diploid 'Grasslands Samson' in June and October $2007(\mathrm{P}<0.05)$ and September in 2008 $(\mathrm{P}=0.08)$. In June 2007, WSC concentration was higher $(\mathrm{P}<0.05)$ in AR1-infected ryegrass than Nil (321 vs 302 $\mathrm{mg} / \mathrm{g} \mathrm{DM}$ ) and again in October (269 vs $258 \mathrm{mg} / \mathrm{g} \mathrm{DM}$ ).

\section{Botanical composition}

There was no consistent effect of cultivar or endophyte on proportion of white clover over the 2 year measurement period (Table 1). Generally clover was slow to establish, contributing less than $5 \%$ of the total DM in the first 6 months. In Year 2 there was a trend towards an increased proportion of clover in swards with Nil endophyte compared to AR1. In December 2008 clover contributed $15.6 \%$ of Nil compared to $8.4 \%$ of DM in AR1 infected swards $(\mathrm{P}<0.05)$. By early April 2009 , the total clover percent had increased and was again tending to be greater $(\mathrm{P}<0.10)$ in Nil $(27 \%)$ than AR1 (19\%) swards. The 'Grasslands Samson' subset containing AR37 showed large variation in clover percent and relative ranking in endophyte status over the experimental period. In June 2008, proportion of clover in plots with AR37 infected ryegrass was lower $(\mathrm{P}<0.05)$ than Nil endophyte plots (Table 1). Weed content increased from 5.4\% in autumn 2007 to $14.1 \%$ of DM in autumn 2009, but differences failed to reach significance because of high data variability. Dock (Rumex obfusifolius) was the dominant weed in the first 8 weeks after sowing, averaging 19 plants $/ \mathrm{m}^{2}$ across treatments, but with slightly $(\mathrm{P}<0.10)$ fewer docks in AR1 (17) than in Nil (21 plants $/ \mathrm{m}^{2}$ ) plots. Six months later, increased ryegrass populations and seasonal conditions reduced dock numbers to 6 plants $/ \mathrm{m}^{2}$ with no treatment differences.

\section{Discussion}

There have been no data published on the agronomic performance of HSG cultivars which have been commercialised in New Zealand. This is rather surprising, as the high sugar trait is highly acclaimed for its potential benefits to yield and animal productivity. Australian work (Smith et al. 1998) found the proposed HSG's 'Aurora' and 'Ba11351' performed poorly relative to local cultivars mainly as a result of severe rust (Puccinia coronata) infection. In NZ, two commercial trials comparing UK derived HSG's with NZ cultivars (diploids and tetraploids) showed the agronomic performance of the UK-bred cultivars, particularly the diploids, compared favourably with the NZ-bred cultivars (Hume et al. 2009, submitted), and were less rust-prone. European comparisons with UK standards have shown inconsistent differences in DM yield (Lee et al. 2001; Marley et al. 2007). One EU-wide series of trials (Halling et al. 2004) showed that although 'Aberdart' consistently had a higher sugar concentration, the DM yield of 'Aberdart' was lower than that of 'Fennema' (the EU control), leading to no significant gain in sugar yield per hectare. However, in the present study, there was no difference in total or 
seasonal DM yield between the standard New Zealand cultivar and the UK-derived HSG.

Concerns as to whether or not HSG's would persist under insect challenge (Edwards et al. 2007b) given controlled environment studies showed that the HSG ('AberDove'), infected with AR1 or AR37 endophyte, contained lower concentrations of both endophyte and alkaloids compared to similarly infected control plants (Rasmussen et al. 2007). Lower endophyte and peramine concentrations in a HSG was also observed in the field (Bryant et al. 2008b), but the possibility of ASW attack was not realised, either due to peramine concentrations remaining above the critical level to deter insects, or through interactions with other metabolites in HSG's. Hume et al. (2007) showed that the advantages of endophyte increased over time, particularly with pastures infected with AR37, as this endophyte strain provides resistance to root aphid feeding (Popay \& Gerard 2007). In the present study, root aphid populations were monitored in the second autumn and colony numbers ranged from 1 to 20 in both AR1 and Nil endophyte plots, but were virtually absent under AR37. Comparison of our results with those of Hume et al. (2007) gave a similar relative ranking, but the level of infestation in their study was three times greater than the low infestation recorded here and was unlikely to result in significant DM losses. In general, the pest challenge to plants in this trial was low and consequently differences in ryegrass DM production due to endophyte infection have not emerged.

A further potential impact is that endophyte may suppress clover growth as observed in controlled experiments, either through increased vigour of the host (Ravel et al. 1997) or via allelopathic effects (Sutherland et al. 1999). In a field study carried out in the Waikato, Thom et al. (1999) showed a trend towards increased clover percent in Nil endophyte pastures compared to those infected with wild-type (or Standard endophyte). Later studies included AR37 endophyte and revealed a significant reduction in the proportion of clover compared to AR1 infected or Nil endophyte ryegrass pastures (Thom 2008). Similar trends were observed in the present study, although the variability in proportion of clover was large, there was no consistent difference between AR1 and Nil or AR37 endophyte treatment.

In this study, expression of the high sugar trait was apparent occasionally (Fig. 4). Sugar concentration of ryegrass plants may also affect the proportion of clover through alteration of grazing preference (Edwards et al. 2007a). Increased partial preference for ryegrass with elevated water soluble carbohydrates over clover was shown in short-term grazing with sheep (Allsop et al. 2009) which has the potential to lift clover composition in the field. However, in the current study, which used block grazing, there was little opportunity for selective grazing so the effect of partial preference on clover composition was not observed.

The tetraploid 'Quartet' was included in this trial as a "high sugar control" as doubling chromosome number increases WSC concentration in ryegrass genotypes with no previous selection for sugar content (Smith et al. 2001). Tetraploids are often noted for lower persistence compared with diploids (Roegiers et al. 1988; Wilkins \& Lovatt 2007) which may be attributed to increased grazing pressure due to high stock acceptance (Bryant et al. 2008a) and/or increased susceptibility to insect damage (Bryant et al. 2008b; Popay et al. 2003). However, we did not observe any detrimental effects of tetraploidy on agronomic performance in our study.

The interaction between plant and endophyte has been well documented (Cheplick \& Cho 2003; Rasmussen et al. 2008) although there is little field information to describe the biological impact of these interactions. Hume et al. (2007) demonstrated variation in ryegrass persistence and productivity when infected with different endophytes. In this study, we used the same cultivar, 'Grasslands Samson', with similar endophyte strains, AR37 and AR1, as used by Hume et al. (2007). However, in our study, no apparent effects of endophyte infection on productivity was seen, which might be due to a lack of repeated biotic and abiotic stress as experienced in the Hume et al. (2007) experiments. Furthermore, relative rankings for cultivar performance vary between North and South Islands (Easton et al. 2001) and expression of the plant/endophyte interaction may depend on the environment to which the plant has adapted. Under the irrigated, low nitrogen input practised in this experiment, the effect of endophyte and cultivar on productivity was minimal.

\section{ACKNOWLEDGEMENTS}

This research was funded by Foundation for Research Science and Technology (Contract C10X0503). Thanks to Lincoln University honours students; Hamish Campbell, Diana Selbie and Geoffrey Smith for assistance in data collection.

\section{REFERENCES}

Allsop, A.R.C.; Nicol, A.M.; Edwards, G.R. 2009.

Effect of water soluble carbohydrate concentration of ryegrass on the partial preference of sheep for clover. Proceedings of the New Zealand Society of Animal Production 69: 20-23.

Bryant, R.H.; Nicol, A.M.; Edwards, G.R. 2008a. Are the cost-benefits of grazing perennial ryegrass cultivars related to preference? Australian Journal of Experimental Agriculture 48: 885-888.

Bryant, R.H.; Parsons, A.J.; Rasmussen, S.; Edwards, G.R. 2008b. Argentine stem weevil damage to high sugar ryegrass infected with AR1 under field conditions. Proceedings of the New Zealand Grassland Association 70: 271-276. 
Cheplick, G.P.; Cho, R. 2003. Interactive effects of fungal endophyte infection and host genotype on growth and storage in Lolium perenne. New Phytologist 158: 183-191.

Cosgrove, G.P.; Burke, J.L.; Death, A.F.; Hickey, M.J.; Pacheco, D.; Lane, G.A. 2007. Ryegrasses with increased water soluble carbohydrate: evaluating the potential for grazing dairy cows in New Zealand. Proceedings of the New Zealand Grassland Association 69: 179-185.

Easton, H.S.; Baird, D.B.; Cameron, N.E.; Kerr, G.A.; Norriss, M.G.; Stewart, A.V. 2001. Perennial ryegrass cultivars: herbage yield in multi-site plot trials. Proceedings of the New Zealand Grassland Association 63: 183-188.

Edwards, G.R.; Parsons, A.J.; Rasmussen, S. 2007a. High sugar ryegrasses for dairy systems. pp. 307334. In: Meeting the challenges for pasture-based dairying. Proceedings of the 3rd Australasian Dairy Science Symposium. Eds. Chapman, D.F., Clark, D.A.; Macmillan, K.L.; Nation, D.P. National Dairy Alliance, Melbourne.

Edwards, G.R.; Parsons, A.J.; Rasmussen, S.; Bryant, R.H. 2007b. High sugar grasses for livestock systems in New Zealand. Proceedings of the New Zealand Grassland Association 69: 161-171.

Halling, M.A.; Longland, A.C.; Martens, S.; Nesheim, L.; O'Kiely, P. 2004. Accumulation of water soluble carbohydrates in two perennial ryegrass cultivars at nine European sites. pp. 954-956. In: Grassland science in Europe. Land use systems on grassland dominated regions. European Grassland Federation 20th General Meeting.

Hume, D.E.; Hickey, M.J.; Lyons, T.B.; Baird, D.B. 2009. Agronomic performance and water soluble carbohydrate expression of selected ryegrasses at two locations in New Zealand. New Zealand Journal of Agricultural Research (Submitted).

Hume, D.E.; Ryan, D.L.; Cooper, B.M.; Popay, A.J. 2007. Agronomic performance of AR37-infected ryegrass in northern New Zealand. Proceedings of the New Zealand Grassland Association 69: 201-205.

Lee, M.R.F.; Jones, E.L.; Moorby, J.M.; Humphreys, M.O.; Theodorou, M.K.; MacRae, J.C.; Scollan, N.D. 2001. Production responses from lambs grazed on Lolium perenne selected for an elevated watersoluble carbohydrate concentration. Animal Research 50: 441-449.

Marley, C.L.; Fraser, M.D.; Fisher, W.J.; Forbes, J.M.; Jones, R.; Moorby, J.M.; MacRae, J.C.; Theodorou, M.K. 2007. Effects of continuous or rotational grazing of two perennial ryegrass varieties on the chemical composition of the herbage and the performance of finishing lambs. Grass and Forage Science 62: 255-264.
Parsons, A.J.; Rasmussen, S.; Xue, H.; Newman, J.A.; Anderson, C.B.; Cosgrove, G.P. 2004. Some 'high sugar grasses' don't like it hot. Proceedings of the New Zealand Grassland Association 66: 265-271.

Popay, A.J.; Gerard, P.J. 2007. Cultivar and endophyte effects on a root aphid, Aploneura lentisci, in perennial ryegrass. New Zealand Plant Protection 60: 223-227.

Popay, A.J.; Hume, D.E.; Davis, K.L.; Tapper, B.A. 2003. Interactions between endophyte(Neotyphodium spp.) and ploidy in hybrid and perennial ryegrass cultivars and their effects on Argentine stem weevil (Listronotus bonariensis). New Zealand Journal of Agricultural Research 46: 311-319.

Rasmussen, S.; Parsons, A.J.; Bassett, S.; Christensen, M.J.; Hume, D.E.; Johnson, L.J.; Johnson, R.D.; Simpson, W.R.; Stacke, C.; Voisey, C.R.; Xue, H.; Newman, J.A. 2007. High nitrogen supply and carbohydrate content reduce fungal endophyte and alkaloid concentration in Lolium perenne. New Phytologist 173: 787-797.

Rasmussen, S.; Parsons, A.J.; Fraser, K.; Xue, H.; Newman, J.A. 2008. Metabolic profiles of Lolium perenne are differentially affected by nitrogen supply, carbohydrate content, and fungal endophyte infection. Plant Physiology 146: 1440-1453.

Ravel, C.; Courty, C.; Coudret, A.; Charmet, G. 1997. Beneficial effects of Neotyphodium lolii on the growth and the water status in perennial ryegrass cultivated under nitrogen deficiency or drought stress. Agronomie 17: 173-181.

Roegiers, P.; Reheul, D.; Bogaert, G.-v. 1988. The persistence of tetraploid perennial ryegrass in a mixture with diploid perennial ryegrass. Journal of Agronomy and Crop Science 161: 40-44.

Smith, K.F.; Simpson, R.J.; Culvenor, R.A.; Humphreys, M.O.; Prud'Homme, M.P.; Oram, R.N. 2001. The effects of ploidy and a phenotype conferring a high water-soluble carbohydrate concentration on carbohydrate accumulation, nutritive value and morphology of perennial ryegrass (Lolium perenne L.). Journal of Agricultural Science, Cambridge 136: 65-74.

Smith, K.F.; Simpson, R.J.; Oram, R.N.; Lowe, K.F.; Evans, P.M.; Humphreys, M.O. 1998. Seasonal variation in the herbage yield and nutritive value of perennial ryegrass (Lolium perenne L.) cultivars with high or normal herbage water-soluble carbohydrate concentrations in three contrasting Australian dairy environments. Australian Journal of Experimental Agriculture 38: 821-830.

Sutherland, B.L.; Hoglund, J.H. 1989. Effect of ryegrass containing the endophyte (Acremonium lolii), on the performance of associated white clover and 
subsequent crops. Proceedings of the New Zealand Grassland Association 50: 265-269.

Sutherland, B.L.; Hume, D.E.; Tapper, B.A. 1999. Allelopathic effects of endophyte-infected perennial ryegrass extracts on white clover seedlings. New Zealand Journal of Agricultural Research 42: 19-26.

Thom, E.R. 2008. AR37 Endophyte research - the story so far. Dairynewz Summer 2008: 8-9.

Thom, E.R.; Clark, D.A.; Waugh, C.D. 1999. Growth, persistence, and alkaloid levels of endophyte-infected and endophyte-free ryegrass pastures grazed by dairy cows in northern New Zealand. New Zealand Journal of Agricultural Research 42: 241-253.

Wilkins, P.W.; Humphreys, M.O. 2003. Progress in breeding perennial forage grasses for temperate agriculture. Journal of Agricultural Science 140: 129-150.
Wilkins, P.W.; Lovatt, J.A. 2007. Chromosome doubling and top-crossing as a means of exploiting heterosis in perennial ryegrass. pp. 52-55. In: Breeding and seed production for conventional and organic agriculture. Proceedings of the XXVI meeting of the EUCARPIA fodder crops and amenity grasses section, XVI meeting of the EUCARPIA Medicago spp group.

Williams, W.M.; Easton, H.S.; Jones, C.S. 2007. Future options and targets for pasture plant breeding in New Zealand. New Zealand Journal of Agricultural Research 50: 223-248. 